DOI: doi.org/10.21009/IJLECR.052.13

Received: 5 June 2019

Revised: 10 June 2019

Accepted: 14 August 2019

Published: 31 December 2019

\title{
DESIGNING ICT COMPETENCES - INTEGRATED SYLLABUSES OF WRITING COURSES (DESIGN AND DEVELOPMENT STUDY OF ENGLISH LANGUAGE EDUCATION STUDY PROGRAM SYLLABUSES)
}

\author{
Syarifah Syifa ${ }^{1, a)}$, Darmahusni $^{1 . b)}$ \\ Universitas Negeri Jakarta, Jakarta, Indonesia ${ }^{1)}$ \\ syarifahsyifa_pmpbi17s2@mahasiswa.unj.ac.id ${ }^{\text {a)}}$,darmahusni@unj.ac.id, b)
}

\begin{abstract}
The development of Information and Communication Technology (ICT) has greatly affected the field of education. ICT allow for a higher quality lessons through collaboration with teachers in planning and preparing resources. ICT also develop some writing skills: spelling, grammar, punctuation, editing and re-drafting. ICTs appear as a strategy to improve learners' difficulties and provide students' growth in the writing skills. Therefore, this research aims to design ICT competences - integrated writing syllabuses for English Language Education Study Program (ELESP) by analyzing the existing writing syllabuses from five universities in Indonesia. The analysis involved the ICT Competences proposed by UNESCO, Digital Media Descriptors of English Profiling Grid (EPG) and other ICT based - theories. The researcher employed Design and Development Research (DDR) as a research design and qualitative research as the research method. The used stages of DDR in this study are conducted need analysis; stating the objectives, developing the preliminary syllabus, evaluate the preliminary syllabus and revising a syllabus prototype. The data sources of this research are 14 existing syllabuses of writing courses of undergraduate English Language Education Study Program. The result of the research revealed that the ICT competences are mostly integrated in the component of Teaching Method and Media in the syllabuses. The highest level of ICT competences applied in the existing syllabus is Knowledge Deepening level. Although, the integration or infusion of ICT competences were explicit and implicit mentioned in the syllabuses of writing subjects. The research then provide the procedure of ICT integration and the design the ICT competences integrated - writing syllabuses; Basic Writing, Professional Writing, Creative Writing, and Academic Writing. The proposed syllabus implemented the skill-based syllabus.
\end{abstract}

Keywords: ICT Competences, Writing Skills, Syllabus Design, DDR, ICT UNESCO Framework

In this 21 st century, the term "technology" is an important issue in many fields including education. Integration of Information, Communication, and Technology (ICT) in education refers to the use of computer based communication that incorporates into daily classroom instructional process. In conjunction with preparing students for the current digital era, teachers are seen as the key players in using ICT in their daily classrooms. This is due to the capability of ICT in providing dynamic and proactive teaching-learning environment 
(Arnseth \& Hatlevik, 2012). The aim of ICT integration is to improve and increase the quality, accessibility and cost-efficiency of the delivery of instruction to students, it also refers to benefits from networking the learning communities to face the challenges of current globalization (Albirini, 2006, p.6). ICT integration also helps teachers to design their lesson plans in an effective, creative and interesting approach that would result in students' active learning. Previous researches proved that use of ICT in teaching will enhance the learning process and maximizes the students' abilities in active learning (Finger \& Trinidad, 2002; Jorge et al., 2003; Young, 2003; Jamieson-Procter et al., 2013).

Nowadays, ICTs appear as a strategy to improve learners' difficulties and provide students' growth in the writing skills. Writing is one of skill which very important in English competence. Besides reading, speaking and listening, writing skill is rather difficult to be mastered. Writing is the skill that processed by human being to produce his or her ideas and thought into written-forms, although the ideas or thought can also produce through spokenforms. It means that through spoken forms will be transferred into written forms. ICT develop some writing skills: spelling, grammar, punctuation, editing and re-drafting (Lewin et al, 2000).

UNESCO has developed the UNESCO ICT-Competence Framework for Teachers (UNESCO, 2011). This framework outlines the competencies that teachers need in order to integrate Information and Communication Technologies (ICTs) into their professional practice. The framework aims to provide guidelines and a basic set of qualifications to develop courses for pre-service or in-service teachers, in order to enable teachers to integrate ICT in a pedagogically effective way. The required competencies are defined as the intersections of the three approaches to teaching - technology literacy, knowledge deepening, and knowledge creation - with the six aspects of a teacher's work, namely, understanding ICT in education, curriculum assessment, pedagogy, ICT, organization and administration and teacher professional learning. ICT Competency Framework for Teachers can be used in developing, infusing and designing ICT based curriculum. This framework can be used as the standard in integrating ICT into curriculum development. So, the researcher of this research applied UNESCO ICT Competency Framework in designing ICT integrated writing syllabus.

A related study conducted by Peregoy and Boyle (2012). They carried a study on using technology in improving learners' reading and writing skills. The results of this study indicated that technology tools enhanced learners' reading and writing skills because they are userfriendly, and learners can learn at a faster and more effective way. The other finding of this study was that leaners learn more effectively when they use technology tools instead of traditional teaching method because the Internet provided a favorable learning environment for learners' learning, facilitated a new platform for learners who can have a convenient access to learning lessons.

Therefore, this research is intended to design ICT competences - integrated syllabuses of writing courses for English Language Education Study Program (ELESP).

\section{METHODS}

A research design of this research is Design and Development Research (DDR). Richey \& Klein (2007) defined the DDR as: "the systematic study of design, development and evaluation processes with the aim of establishing an empirical basis for the creation of instructional and non-instructional products and tools and new or enhanced models that govern their development." This definition has similar meaning to the aim of this research in order to design ICT competences - integrated syllabuses of writing courses.

The researcher adapts the research steps into five stages. The steps are elaborated in the 
following figure.

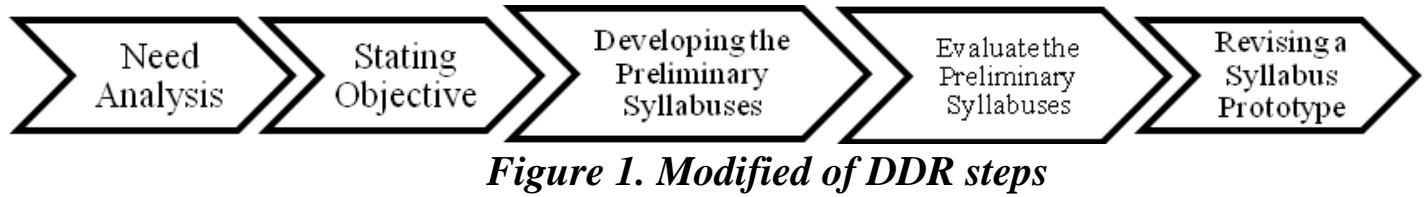

Those five steps of the modified DDR procedures are elaborated as follow:

\section{Need Analysis}

In this step, the researcher conducted need analysis. The researcher collected information from relevant theories related to syllabus design which cover students' needs of writing and ICT competences as well as pedagogical aspects which are teaching, learning and assessment. Besides collecting information from experts' theories, an examination to the existing syllabuses of writing which currently uses by ELESP of some universities in Indonesia conducted as well to enrich the researcher's reference.

\section{Stating Objectives}

The second step after collecting information related to the aspect of syllabus design is stating the objectives. Related to syllabus design model, this step covers deciding key teaching principles, goals, content, sequencing content, syllabus format, and ways of materials presentation, as well as types of assessment employed in the new syllabus prototype.

3. Designing Preliminary Syllabuses

This step formulated from the three experts; Richey and Klein (2005), Borg and Gall (2003), Ellis and Levy (2010). It is the process as the result of need analysis. After finding the gap between the literature review of ICT competences and the existing syllabuses of writing courses, the prototype syllabuses can be produced.

\section{Evaluate the Preliminary Syllabuses}

This step formulated to evaluate and validate the prototypes syllabuses design of syllabuses of writing courses. It is also as the process of expert judgment about the prototype syllabuses design.

\section{Revising a Syllabus Prototype}

After the experts gave their feedbacks and suggestions towards the prototype syllabuses design, the researcher revised the syllabuses to be better in quality. The final product will be a set of syllabuses prototype that can be developed further to be more applicable for writing subjects in ELESP.

\section{RESULTS AND DISCUSSIONS}

Some analyses are conducted to get the result of study. The analysis was conducted to get the answer of how the ICT competences - integrated syllabuses of writing courses for English Language Education Study Program (ELESP). After formulating and analyzing the data descriptively, it can be found findings in this research; the analysis of existing syllabuses, the procedures of integrating ICT competences in the syllabuses of writing courses, and the design of the syllabuses of writing courses integrated ICT competences elaborated.

\section{The Analysis of Existing Syllabuses}

This part is done in order to answer the first sub-question of this research which is "To what extent are the ICT Competences - Integrated in the existing writing syllabuses for ELESP?". This question explicitly seeks response about the substances of the existing syllabuses. Therefore, the analyses in this section is divided into two identifications: firstly, identify the existing syllabus components, and secondly identify ICT competences.

The researcher found the components that emerge in the existing syllabus by 
investigating the existing syllabus components. The components of syllabus that has been found then be compared with the components of syllabus from some experts such as Altman and Cashin (1992), Davis (2006), Dilllon (2013), as well as Permendikbud (2014) suggest various components to be put in a syllabus. They are: Basic Information, Course Description, Learning Outcomes, Schedule, Learning Objectives, Materials/Topic, Teaching Method, Learning Activities, Time allocation, Learning Media, Indicators, References, Assignment, Assessment, Course policy, and Contact Information of the lecturer. The analysis of the syllabus components in existing syllabuses is displayed in Figure 2 below.

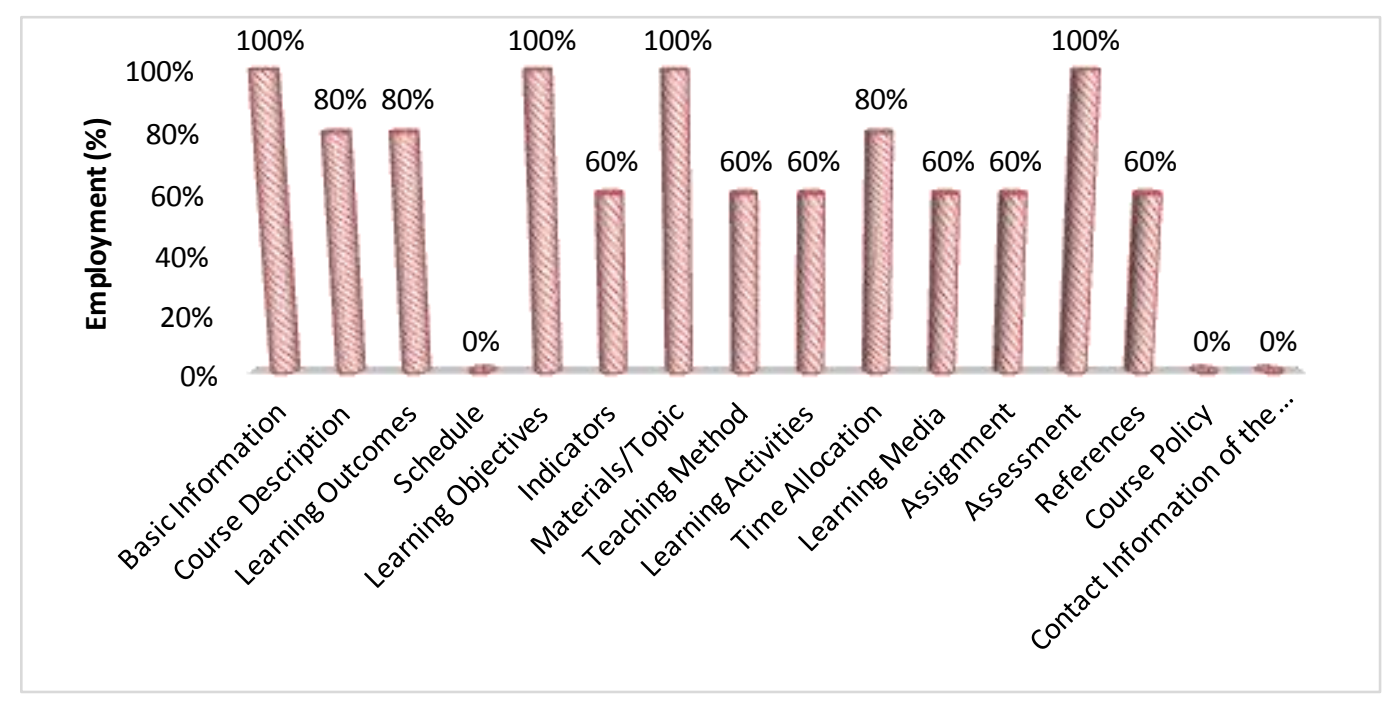

Figure 2. Syllabus Components in the Existing Syllabuses

From the figure above it can be seen that the syllabus components proposed by experts are not fully and completely employed by the existing syllabus, it means that these syllabus components are still needed to be developed and evaluated. However, some components are not employed concurrently. The component employments are discussed further as follow:

- From the 14 existing syllabuses, only four the existing syllabuses employ Basic Information, Learning Objectives, Materials/Topic, and Assessment. This agreement between experts' opinions and application in existing syllabus means that these components are significantly needed and considered important in a syllabus.

- The Course Description, Learning Outcome, Time Allocation are employed by the majority universities. This finding shows a gap between theories and existing state.

- Schedule, Course Policy, Contact Information of the lecturer are considered less important. This judgment is shown by the infrequent employment of these components in the existing syllabus. This view show disagreement between the expert theory and syllabus application.

Meanwhile, there are some components found in the existing syllabuses that are not proposed by the experts, for example is learning/teaching media. Having the result, the researcher in the designing new syllabuses employs all of these components and add another component such as learning media to be involved in the purposed syllabuses of writing.

The next analysis is pertaining to the involvement of ICT competences in the existing syllabuses of writing. The researcher identifies the ICT competences that appear in 
the syllabus' elements; Course Description, Learning Objectives, Materials, Teaching Methods and Assessments. Then, the competences in the existing syllabus are compared with the ideal state that how the ICT can be infused as represented in ICT framework which is explained in literature review. The ICT competences indicators are mostly integrated in the components of Teaching Method (TM). These components are integrated explicitly and implicitly in all syllabuses from five universities. However the components of Assessment (A), Assignment (AS) also have been integrated explicitly and implicitly with ICT competences in syllabuses from three universities. The others ICT competences integrated components are Topics (T) or Materials (M) and Learning Objectives (LO). The ICT competences which are integrated most in the existing syllabus components are the competences of using common hardware in supporting teaching and learning activity (Class Computer, Laptop/Notebook, Projector, LCD) (U4), and the competence of using presentation software and digital resources to support teaching and learning activity (Microsoft PowerPoint). The existing syllabuses have been indicating all levels of ICT competence; Technology Literacy, Knowledge Deepening and Knowledge Creation. However, Knowledge Deepening is mostly applied in the syllabuses from five universities. The second level found in the existing syllabus is Technology Literacy and the least level found in the existing syllabuses is Knowledge Creation.

\section{The Procedures of Integrating ICT Competences in the Writing Syllabuses for English Language Education Study Program (ELESP)}

The procedure in integrating ICT Competences in syllabuses of Practical Key Teaching Competences is to answer the second sub-research question. The procedure in integrating ICT as follows:

1. Identifying indicators of ICT competences from various reference sources;

2. Choosing ICT competences that are in accordance with the general competences of writing subjects;

3. Analyzing the writing syllabus components or course planning (RPS) components that can contain or accommodate ICT competences related to or in accordance with the function of those components;

4. Matching ICT competences with syllabus components of writing courses that can contain or accommodate ICT competences;

5. Inserting or infusing ICT competences into the writing syllabus components by inserting key points of ICT competence indicators into the statements contained in the syllabus component so that they are integrated or becoming part of the statement;

6. Evaluate the designs of syllabuses of writing courses integrated ICT competences;

7. Revise the designs of syllabuses of writing courses integrated ICT competences.

\section{The Design of ICT Competences - Integrated Syllabuses of Writing Courses for ELESP}

This study aims to design ICT competences - integrated syllabuses of writing for ELESP. In designing the syllabi, a skill-based approach to syllabus design is applied.

From the analysis of ICT competences infusion in syllabus components, also the gaps found from writing syllabuses, the researcher then tried to design the ICT competences integrated writing syllabuses of Basic Writing, Professional Writing, Creative Writing, and Academic Writing. 


\section{CONCLUSION}

Based on the findings of this research, for the first sub question, it was found that from the 14 existing syllabuses that has been analyzed, only four syllabus components applied by those five universities, such as Basic Information, Learning Objectives, Materials/Topic and Assessment. Then, for the result of the next analysis related to the involvement of ICT competences in the existing syllabuses of writing, after the researcher identified the ICT competences that appear in the syllabus' elements such as Course Description, Learning Objectives, Materials, Teaching Methods and Assessments, the competences in the existing syllabus are compared with the ideal state that how the ICT can be infused as represented in ICT framework which is explained in literature review. Based on the table of analysis of ICT employment in the existing syllabuses found that among the 14 syllabus components, the ICT is mostly stated in the Teaching Media/Learning Media. The existing syllabuses have been indicating all levels of ICT competences; Technology Literacy, Knowledge Deepening and Knowledge Creation. However, Knowledge Deepening is mostly applied in the syllabuses from five universities.

Second, it can be concluded there are eight steps of procedure in designing ICT competences - integrated syllabuses of writing courses as follows; (1) Identifying indicators of ICT competences from various reference sources; (2) Choosing ICT competences that are in accordance with the general competences of writing subjects; (3) Analyzing the writing syllabus components or course planning (RPS) components that can contain or accommodate ICT competences related to or in accordance with the function of those components; (4) Matching ICT competences with syllabus components of writing courses that can contain or accommodate ICT competences; (6) Inserting or infusing ICT competences into the writing syllabus components by inserting key points of ICT competence indicators into the statements contained in the syllabus component so that they are integrated or becoming part of the statement; (7) Evaluate the designs of syllabuses of writing courses integrated ICT competences; (8) Revise the designs of syllabuses of writing courses integrated ICT competences.

The syllabus components can be integrated ICT in new prototype syllabuses of writing courses such as basic information, course description, materials/topic, teaching method and media, assessment, course policies, and references. It is integrated implicitly and explicitly.

Third, the proposed syllabuses of Basic Writing, Professional Writing, Creative Writing, and Academic Writing integrated ICT competences are designed. The proposed syllabus implemented the skill-based syllabus. The proposed-syllabuses of writing courses are integrated by ICT competences implicitly and explicitly into the entire syllabus components except learning objectives and learning outcomes.

\section{REFERENCES}

Baytak, A., Tarman, B., and Ayas, C. (2011). Experiencing technology integration in education: children's perceptions. International Electronic Journal of Elementary Education, 3(2), 139151. https://www.iejee.com/index.php/IEJEE/article/view/233. Date accessed: 17 June 2018.

Bennett, D., Culp, K. M., Honey, M., Tally, B., and Spielvogel, B. (2000). It all depends: Strategies for designing technologies for educational change. Paper presented at the International Conference on Learning Technology, Philadelphia, PA.

Borg, W.R. and Gall, M.D. (1983). Educational Research: An Introduction. NY: Longman Inc

Brown, James Dean. (1995).The Elements of Language Curriculum: A Systematic Approach to Program Development. USA: Heile and Heilne Publishers.

Brown, J. (1995). The elements of language curriculum (p. chapter 3 goals and objectives). p. 
chapter 3 goals and objectives.

Brown, H. Douglas. (2001). Teaching by Principles: An Interactive Approach to Language Pedagogy, Second Edition. New York: Pearson Education.

Brown, H. D., \& Abeywickrama, P. (2010). Language Assessment - Principles and Classroom Practices ( 2 ed.). New York: Pearson Education Inc.

Cambridge, U. of. (2011). Using the CEFR: Principles of Good Practice, (October), 46. Retrieved from http://www.cambridgeenglish.org/images/126011-using-cefr-principles-of-goodpractice.pdf

Council of Europe. (2001). Common European Framework of Reference for Languages : Learning, teaching, assessment Structured.

Ed, F. M., \& Hqs, P. A. D. U. (n.d.). ICT Competency Standard for Teachers and Institutional Strategy for Teacher Training on ICT-pedagogy Integration.

Creswell, J. W. (2009). Research Design Qualitative, Quantitative and Mixed Methods Approaches. California: SAGE Publication, Inc.

Davis, B. G. (2004). Components of a Course Syllabus. Mellon Faculty Institute on Undergraduate Research, (June), 1-4.

Davis, B.G. (2009). Tools for Teaching. John Wiley \& Sons.

Ellis, R. (2012). Language Teaching Research and. United Kingdom: John Wiley \& Sons.

Gall, M. D., Gall, J. P., and Borg, W. R. (2003). Educational Research (Seventh edition). Educational Research: An introduction (7th ed.). Boston: Pearson Education. Retrieved from http://psycnet.apa.org/psycinfo/1996-97171-000

Graves, K. (2000). Designing Language Courses: A Guide for Teacher. Boston: Heinle \& Heinle.

Harmer, J. (2007). The practice of English language teaching. England: Pearson.

www.worldcat.org/title/practice-of-englishlanguageteaching/oclc/149005881

Kemenristekdikti. (2017). Penetapan Standar Pendidikan Tinggi.

KEMENRISTEKDIKTI. (2016). Panduan Penyusunan Kurikulum Pendidikan Tinggi. RISTEKDIKTI.

Murphy, R. S. (2018). The Concept of Syllabus Design and Curriculum Development: A Look at Five Major Syllabus Designs. Research Gate, (February).

Nation, P., and Macalister, J. (2010). Language Curriculum Design. Routledge. New York: Routledge. https://doi.org/10.1136/bmj.326.7383.268

Nunan, D. (1988). Syllabus Design (Language Teaching: A Scheme for Teacher Education).

Oxford: Oxford University Press

Nunan, D. (2003). Practical English Language Teaching. Boston: McGraw Hill.

Reilly, T. (1988). Approaches to foreign languages syllabus design. ERIC Clearinghouse onLanguages and Linguistics, Washington DC. Retrived from ERIC Data Based ED:295460.

Richards, J. C., and Renandya, W. A. 2002. Methodology in Language Teaching: An Arthology of Current Practice. Cambridge: Cambridge University Press.

Richards, J. (2001). Curriculum Development in Language Teaching. Cambridge: Cambridge University Press.

Richards, J. (2013). Curriculum Approaches in Language Teaching: Forward, Central, and Backward Design. University of Sydney, Australia; RELC, Singapore.RELC Journal 44(1) 533.

Richards, J., and Rodgers, T. (2001). Approaches and methods in language Teaching (2nd ed.). Cambridge: Cambridge University Press, p.164.

Sugiyono. (2007). Metode Penelitian Kuantitatif Kualitatif dan R\&D. Bandung: Alfabeta.

UNESCO. (2008). ICT Competence Standards for Teachers Implementation Guidelines. Paris; UNESCO. 
UNESCO. (2011). UNESCO ICT Competency Framework for Teachers. Paris; UNESCO.

Ur, P. (2003). A course in language teaching: Practice and theory. United Kingdom: Cambridge University Press.

Wademan, M. R. (2005). "Utilizing development research to guide People Capability Maturity Model adoption considerations" Instructional Design, Development and Evaluation -

Dissertations. 12. Retrieved from https://surface.syr.edu/idde_etd/12 https://en.wikipedia.org/wiki/Professional_writing https://www.urbanpro.com/creative-writing/4-types-writing-skills 